\title{
Karakterisasi Enzim Pendegradasi AHL dari Bacillus cereus INT1c dan Bacillus sp. NTT3a
}

\section{Characterization of AHL Degrading Enzyme from Bacillus cereus INT1c and Bacillus sp. NTT3a}

\author{
Susi Ratnaningtyas ${ }^{1}$, Iman Rusmana ${ }^{1^{*}}$, Alina Akhdiya ${ }^{2}$

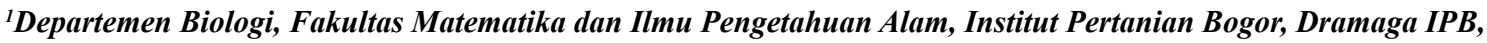 \\ Bogor, Jawa Barat, 16680 Indonesia \\ ${ }^{2}$ Balai Penelitian dan Pengembangan Bioteknologi Pertanian dan Sumberdaya Genetika Indonesia, Cimanggu, \\ Bogor, Jawa Barat, Indonesia
}

Diterima 7 Agustus 2017 /Disetujui 10 Oktober 2017

\begin{abstract}
Some of Gram-negative bacteria perform a phenomenon called quorum sensing (QS) to activate certain phenotypes such as pathogenicity. The bacterial cells performing QS produce $\mathrm{N}$-acyl homoserine lactone (AHL) as signal molecules to communicate within population. These molecules can be degraded by the enzyme, i.e. AHL lactonase. This study aimed to characterize the activity of AHL lactonase from Bacillus cereus INT1c and Bacillus sp. NTT3a in different pH and temperature levels. Both strains produce AHL-lactonase that could be found in intracellular and extracellular extracts. The dialysis process of extracellular AHL-lactonase of INT1c significantly increased the specific activity from 5.91 to 29.96, different from extracellular enzyme of NTT3a that slightly increased from 4.08 to 5.39. Generally dialyzedAHL-latonase of both B. cereus INT1c and Bacillus sp. NTT3a had activity in wide $\mathrm{pH}$ range with better activity in acidic $\mathrm{pH}$ and were not stable in high temperature with the highest activity at $30-40{ }^{\circ} \mathrm{C}$.
\end{abstract}

Key words: Anti-quorum sensing, enzim pendegradasi AHL, AHL-laktonase, Bacillus cereus

\section{PENDAHULUAN}

Sel bakteri menghasilkan molekul sinyal sebagai media komunikasi yang dapat menggambarkan kepadatan sel di dalam populasinya. Fenomena ini disebut quorum sensing(QS). Ketika kepadatan selnya mencapai quorum, bakteri kemudian mengekspresikan gen untuk fenotipe tertentu seperti faktor virulensi, luminesensi, pembentukan biofilm, dan transferplasmid. Molekul sinyal QS yang banyak dipelajari adalah $\mathrm{N}$-acylhomoserine lactone (AHL) yang dihasilkan oleh bakteri Gram-negatifdan peptida yang dihasilkan oleh bakteri Gram-positif (Kalia 2013). Beberapa bakteri patogen seperti Erwinia carotovora, E. stewartii, Agrobacterium tumefaciens, Vibrio harveyi, dan V. fischeri menghasilkan molekul sinyal AHL dalam melakukan quorum sensing untuk ekspresi faktor irulensi (de Kievit \& Iglewski 2000).

Pendekatan tradisional dalam melawan infeksi bakteri patogen tersebut umumnya menggunakan antibiotik atau senyawa antimikrob aktif lain untuk

*Penulis korespondensi :

E-mail: irusmana@ipb.ac.id memutus siklus hidup bakteri dengan menghambat sintesis dinding sel, replikasi DNA atau sintesis protein. Meskipun efektif melawan infeksi bakteri, senyawasenyawa tersebut mengakibatkan tekanan pada bakteri target dan menghasilkan seleksi subpopulasi bakteri yang resisten (Rasko dan Sperandio 2010). Pendekatan lain adalah dengan tidak menghambat pertumbuhan bakteri melainkan menghambat virulensinya. Sistem QS yang mengaktifkan sifat virulensi pada bakteri dapat diganggu dengan proses anti-quorum sensing dengan senyawa tertentu yang dihasilkan prokariot maupun eukariot yang tergolong sebagai quorum sensing inhibitor (QSI) (Kalia 2013). Kelebihan dari pendekatan ini adalah menimbulkan tekanan evolusi yang lebih rendah dalam membentuk resistensi, tidak seperti antibiotik (Dell'Acqua et al. 2004; Rasko dan Sperandio 2010). Selain itu, QSI juga mampu menghambat pembentukan biofilm sehingga bakteri lebih rentan bahkan terhadap antibiotik dengan dosis rendah (Dell'Acqua et al. 2004).

Quorum sensing inhibitor yang dihasilkan oleh prokariot dapat berupa enzim yang mendegradasi sinyal QS. Enzim yang dikenal mendegradasi sinyal AHL ialah AHL-laktonase dan dekarboksilase yang 
menghidrolisis cincin lakton, dan AHL-asilase dan deaminase yang memotong rantai samping asil (Kalia 2013). Enzim AHL asilase ditemukan salah satunya pada Ralstonia sp. XJ12B dan Pseudomonas aeruginosa PAO1 sedangkanAHL-laktonase contohnya ditemukan pada berbagai spesies Bacillus spp serta Agrobacterium tumefaciens, Arthrobactersp., danKlebsiellapneumonia. AHL-lactonase (AiiA) yang ditemukan pada spesiesspesies Bacillus memiliki tingkat kemiripan peptida penyusun sebesar 90\% (Huang et al. 2003; Dong dan Zhang 2005). Bakteri yang juga menghasilkan AHL-laktonase adalah Bacillus cereus INT1c (Afiah 2011) dan Bacillus sp. NTT3a (Fitriyah 2011) yang diisolasi dari tanah pertanian di Indramayu Jawa Barat dan Nusa Tenggara Timur. Kedua bakteri tersebut telah diidentifikasi berdasarkan sifat morfologi dan molekuler menggunakan gen $16 \mathrm{~S}$ rRNAdan gen aiiA. Sebelum digunakan sebagai anti-quorum sensing, sifat aktivitasAHL-laktonase perlu diketahui terlebih dahulu. Penelitian inibertujuan untuk mengkarakterisasi enzim AHL-laktonase dari B. cereus INT1c dan Bacillus sp. NTT3a pada rentang $\mathrm{pH}$ dan suhu tertentu sehingga dapat diketahui kondisi yang optimum bagi enzim untuk bekerja paling optimal dalam menghambat proses quorum sensing pada Chromobacterium violaceum. Hasil penelitian ini memberikan informasimengenaipH optimal dan suhu optimal dari enzim AHL-laktonase $B$. cereus INT1 1 dan Bacillus sp. NTT3a sehingga dapat digunakan sebagai acuan dalam mengembangkan agen anti-quorum sensing khususnya dari jenis Bacillus.

\section{BAHAN DAN METODE}

Bahan. Bakteri yang digunakan dalam penelitian adalah Bacillus cereus INT1c (Afiah 2011), Bacillus sp. NTT3a (Fitriyah 2011) dan bakteri bioindikator Chromobacterium violaceum.

Pemeliharaan, penyiapan inokulum bakteri. Bacillus cereus INT1c dan Bacillus sp. NTT3a ditumbuhkan pada media Luria Bertani (LB) Agar dengan komposisi yeast extract $5 \mathrm{~g} / \mathrm{L}$, tripton $10 \mathrm{~g} / \mathrm{L}$, $\mathrm{NaCl} 10 \mathrm{~g} / \mathrm{L}$, dan $15 \mathrm{~g} / \mathrm{L}$ agar-agar. Kultur diinkubasi pada suhu $27{ }^{\circ} \mathrm{C}$ selama 24 jam kemudian langsung digunakan sebagai inokulum padat atau disimpan dalam lemari pendingin sebagai stok biakan kerja. $\operatorname{Kultur} C$. violaceum diremajakan pada media $L B$ cair kemudian diinkubasi pada suhu ruang di atas shaker selama 24 jam atau hingga kultur berwarna ungu untuk digunakan sebagai bioindikator pada pengujian aktivitas AHLlaktonase atau disimpan sebagai stok biakan kerja.

Uji aktivitas Quorum Quenching dengan teknik disc diffusion assay. Aktivitas quorum quenching AHLlaktonase terhadap C. violaceum diuji dengan teknik disc diffusion assay sebagaimana dipublikasikan oleh
Fitriyah et al.(2015). Delapan puluh mikroliter sampel enzim diteteskan pada paper disc steril (diameter 8 $\mathrm{mm}$, ketebalan $1.5 \mathrm{~mm}$,ADVANTEC, Japan) kemudian diletakkan pada permukaan media agar LB semipadat ( $0.8 \%$ agar) yang mengandung $1 \%(\mathrm{v} / \mathrm{v})$ kultur cair $C$. violaceum $(108 \mathrm{cfu} / \mathrm{mL})$. Biakan diinkubasi pada suhu ruang selama $24 \mathrm{jam}$. Aktivitas degradasi AHL oleh AHL-laktonase ditandai dengan adanya zona tidak ungu (zona quorum quenching) di sekeliling paper disc. Kuantitasi aktivitas AHL-laktonase dilakukan dengan caramenghitung nilai indeks quorum quenching (QQ) menggunakan rumus berikut:

$$
\text { Indeks } Q Q=\frac{\text { Diameter zona } Q Q(\mathrm{~mm})-\text { Diameter paper disc }(\mathrm{mm})}{\text { Diameter paper disc }(\mathrm{mm})}
$$

ProduksiAHL-laktonase. Sebanyak $5 \mu$ Linokulum tersebut digunakan untuk menginokulasi $500 \mathrm{mLkaldu}$ LB dan diinkubasi pada inkubator goyang pada suhu $27^{\circ} \mathrm{C}$ selama 9 jam $\left(\mathrm{OD}_{600} 1.2\right)$. Selanjutnya kultur disentrifugasi (Himac CR21G, Japan) pada kecepatan $10000 \times g$, suhu $4^{\circ} \mathrm{C}$ selama 15 menit. Supernatan yang diperoleh digunakan sebagai sumber enzim ektraseluler kasar sedangkan pelet sel diresuspensi dengan menggunakan buffer Phosphate Saline Buffer (PBS) $10 \mathrm{mMpH}$ 7.4yang telah didinginkan sebelumnya. Suspensisel disentrifugasi(HERMLEZ326K, Denmark) dengan kecepatan $6000 \mathrm{rpm}$ selama 10 menit pada suhu $4{ }^{\circ} \mathrm{C}$. Pelet sel yang telah dicuci diresuspensi kembali dengan PBS sebelum dilisis dengan menggunakan sonikator (Soniprep-150, UK). Sonikasi dilakukan $5 \times 2$ menit pada $25 \mathrm{kHz}$ dengan jeda antar masingmasing sonikasi selama 2 menit di ice bath. Hasil sonikasi disentrifugasi dengan kecepatan $12500 \times g$ selama 15 menit pada suhu $4^{\circ} \mathrm{C}$ (HERMLE Z326K, Denmark). Supernatan yang diperoleh digunakan sebagai sumber enzim intraseluler kasar (Dong et al. 2002). Selanjutnya enzim AHL-laktonase kasar diendapkan menggunakan amonium sulfat pada tingkat saturasi 70\% (Scopes 1987). Endapan enzim yang diperoleh diresuspensi dengan buffer fosfat $\mathrm{pH} 7$. Hasil pemekatan kemudian didialisis menggunakan kantong dialisis (Sigma-Aldrich D0405) berukuran 12400 MWCO selama 12 jam. Kadar protein pada enzim dari setiap tahap penyiapan diukur menggunakan metode standard (Bradford(1976)) dengan standar protein Bovine serum albumin (BSA). Absorbansi diukur menggunakan spektrofotometer (Genesys 20, Germany) pada panjang gelombang $595 \mathrm{~nm}$.

\section{Pengukuran pengaruh suhu dan $\mathrm{pH}$ terhadap} aktivitas AHL-laktonase. Enzim hasil pemekatan dan dialisis dikarakterisasi berdasarkan aktivitasnya pada berbagai suhudan $\mathrm{pH}$. Pengamatan pengaruh suhu terhadap aktivitas enzim dilakukan pada suhu 
20-90 ${ }^{\circ} \mathrm{C}$ dengan jarak $10^{\circ} \mathrm{C}$. Sebanyak $120 \mu \mathrm{L}$ sampel enzim diinkubasi pada suhu 20, 30,40, 50, $60,70,80$ dan $90^{\circ} \mathrm{C}$ selama 10 menit. Pengaruh $\mathrm{pH}$ terhadap aktivitas enzim ditentukan dengan mencampurkan enzim dengan buffer tertentu dengan perbandingan 1:1 sehingga diperoleh larutan enzim yang diharapkan. Larutan enzim tersebut diinkubasi selama 30 menit pada suhu ruang. Pengaturan $\mathrm{pH}$ larutan enzim menjadi $\mathrm{pH}$ 4.0, 5.0, dan 6.0 dilakukan dengan buffer sitrat 0.1 $\mathrm{M}, \mathrm{pH}$ 7.0dan 8.0 dengan buffer fosfat $0.1 \mathrm{M}$, dan pH 9.0 dan 10.0 dengan buffer glisin- $\mathrm{NaOH} 0.1 \mathrm{M}$. Enzim yang telah diberi perlakuan suhu atau $\mathrm{pH}$ diuji aktivitas quorum quenchingnya dengan teknik disc diffusion assay.

\section{HASIL}

Aktivitas AHL-laktonase Bacillus cereus INT1c dan Bacillus sp. NTT3a. Hasil verifikasi menunjukkan bahwa Bacillus cereus INT1c dan Bacillus sp. NTT3a mampu memproduksi enzim AHL-laktonase. Hal ini ditunjukkan dengan adanya zona tidak ungu (zona quorum quenching) yang terbentuk di sekitar paper disc yang telah ditetesi supernatan kultur Bacillus (Gambar 1). Zona quorum quenching juga teramati di sekitar paper disc yang telah ditetesi ekstrak sel (lisat sel) Bacillus. Hal ini menunjukkan bahwa AHLlaktonase aktif terdapat pada supernatan (estraselular) maupun ekstrak sel Bacillus (intrasel).

Aktivitas AHL-laktonase hasil pemekatan dan dialisis. Pengujian terhadap enzim kasar (supernatan kultur), hasil pemekatan, dan dialisis menunjukkan indeks quorum quencing yang berbeda

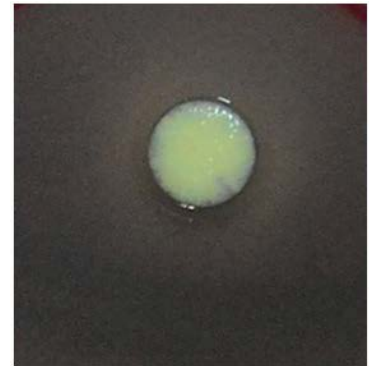

(A)

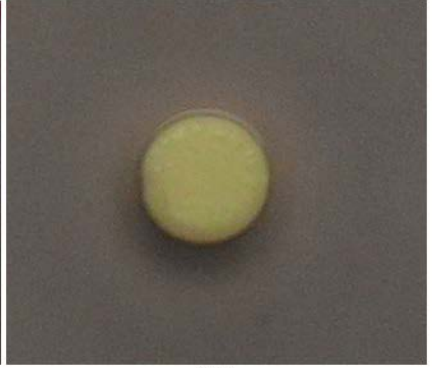

(B)
Gambar 1. Penghambatan produksi violacein Chromobacterium violaceum oleh AHL-laktonase yang terkandung dalam supernatan Bacillus cereus INT1c (A) dan Bacillus sp. NTT3a (B)

Indeks quorum quenching tertinggi dihasilkan oleh enzim hasil pemekatan (Tabel 1). Namun kadar protein dalam enzim yang diujikan tidak sama sehingga perlu ditentukan tingkat aktivitas spesifiknya. Aktivitas spesifik diperoleh dengan membagi nilai indeks quorum quenching dengan kadar protein dari masing-masing enzim.Aktivitas spesifikAHL-laktonase ektraseluler jauh lebih tinggi dibandingkan AHL-laktonase intraseluler (Gambar 2). Aktivitas enzim B. cereus INT1c menurun setelah proses pemekatan namun setelah didialisis aktivitas spesifiknya meningkat dan lebih tinggi dari supernatan. Hasil yang berbeda ditemukan pada enzim ekstraseluler Bacillus sp NTT3a. Aktivitas enzim menurun setelah proses pemekatan dan tetap rendah setelah dialisis. Proses pemekatan enzim intraseluler dari kedua bakteri dapat meningkatkan aktivitas spesifik AHL-laktonase.

Tabel 1. Aktivitas enzim dan total protein yang berasal dari setiap tahap permunian yang berbeda

\begin{tabular}{|c|c|c|c|c|c|c|c|}
\hline Strain Bakteri & Jenis Enzim & Tahap Pemurnian & Volume $(\mathrm{mL})$ & $\begin{array}{l}\text { Indeks Quorum } \\
\text { quenching }\end{array}$ & $\begin{array}{l}\text { Kadar Protein } \\
(\mathrm{mg} / \mathrm{mL})\end{array}$ & $\begin{array}{l}\text { Total Protein } \\
\text { (mg) }\end{array}$ & $\begin{array}{r}\text { Aktivitas } \\
\text { Spesifik }\end{array}$ \\
\hline \multirow{6}{*}{ INT1c } & \multirow{3}{*}{ Ekstraseluler } & Supernatan kultur & 380 & 0.281 & 0.015 & 5.510 & 18.73 \\
\hline & & $\begin{array}{l}\text { Pemekatan } \\
\text { (NH4)2SO4 }\end{array}$ & 30 & 1.094 & 0.185 & 5.535 & 5.91 \\
\hline & & Dialisis & 55 & 0.719 & 0.024 & 1.333 & 29.96 \\
\hline & \multirow{3}{*}{ Intraseluler } & Supernatan kultur & 6.25 & 0.344 & 0.636 & 3.978 & 0.54 \\
\hline & & $\begin{array}{l}\text { Pemekatan } \\
\left(\mathrm{NH}_{4}\right)_{2} \mathrm{SO}_{4}\end{array}$ & 3 & 0.719 & 0.561 & 1.682 & 1.28 \\
\hline & & Dialisis & 4.725 & 0.656 & 0.495 & 2.340 & 1.33 \\
\hline \multirow{6}{*}{ NTT3a } & \multirow{3}{*}{ Ekstraseluler } & Supernatan kultur & 380 & 0.344 & 0.025 & 9.371 & 13.76 \\
\hline & & $\begin{array}{l}\text { Pemekatan } \\
\left(\mathrm{NH}_{4}\right)_{2} \mathrm{SO}_{4}\end{array}$ & 10 & 1.188 & 0.291 & 2.908 & 4.08 \\
\hline & & Dialisis & 27.611 & 0.625 & 0.116 & 3.193 & 5.39 \\
\hline & \multirow{3}{*}{ Intraseluler } & Supernatan kultur & 7.05 & 0.375 & 0.643 & 4.535 & 0.58 \\
\hline & & $\begin{array}{l}\text { Pemekatan } \\
\left(\mathrm{NH}_{4}\right)_{2} \mathrm{SO}_{4}\end{array}$ & 3 & 1.000 & 0.725 & 2.176 & 1.38 \\
\hline & & Dialisis & 4.575 & 0.750 & 0.590 & 2.700 & 1.27 \\
\hline
\end{tabular}




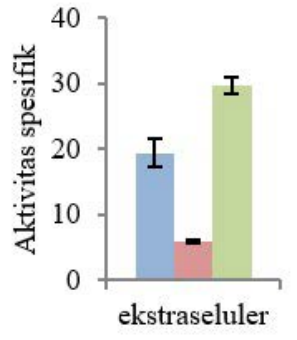

(A1)

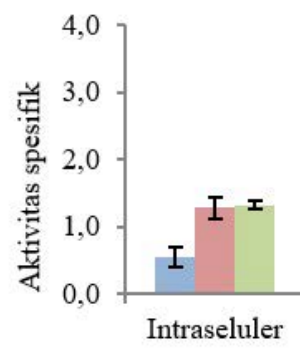

(A2)

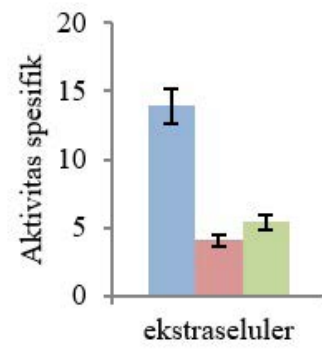

(B1)

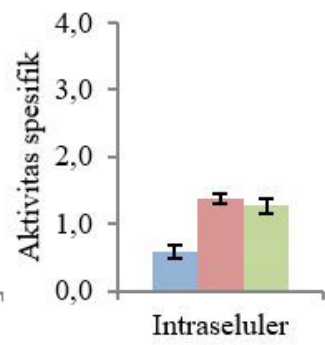

(B2)

Gambar 2. Aktivitas spesifik AHL-laktonase B. cereus INT1c (A) dan Bacillus sp. NTT3a (B) pada tahap supernatan kultur ( setelah pemekatan $(\square)$, dan setelah dialisis $(\square)$

Karakterisasi aktivitas enzim AHL-laktonase Bacillus cereus INT1c dan Bacillus sp. NTT3a. Enzim ekstraseluler B. cereus INT1c hasil pemekatan dengan amonium sulfat memiliki aktivitas yang relatif sama pada $\mathrm{pH}$ 4.0-10.0 dan aktivitas tertinggi terdapat pada $\mathrm{pH}$ 5.0. Enzim AHL-laktonase intraseluler $B$. cereus INT1c memiliki aktivitas optimal pada $\mathrm{pH}$ 4.0-7.0 (Gambar 3 A1). Aktivitas degradasi AHL paling tinggi oleh enzim ekstraseluler $B$. cereus INT1c hasil dialisis terdapat pada $\mathrm{pH} 4.0$ sedangkan enzim intraseluler terdapat pada pH 4.0-5.0 (Gambar 3 A2). Enzim ektraseluler Bacillus sp. NTT3a hasil pemekatan dengan amonium sulfat memiliki aktivitas paling tinggi pada $\mathrm{pH} 6.0$ sedangkan aktivitas optimal enzim intraseluler terdapat pada $\mathrm{pH}$ 4.0-6.0 (Gambar 3 B1). Enzim ekstraseluler Bacillus sp. NTT3a hasil dialisis memiliki aktivitas yang relatif sama pada $\mathrm{pH}$ 4.0-10.0 dengan aktivitas tertinggi pada $\mathrm{pH}$ 4.0-5.0, sedangkan aktivitas tertinggi enzim intraseluler hasil dialisis terdapat pada $\mathrm{pH} 8.0$ (Gambar $3 \mathrm{~B} 2$ ).

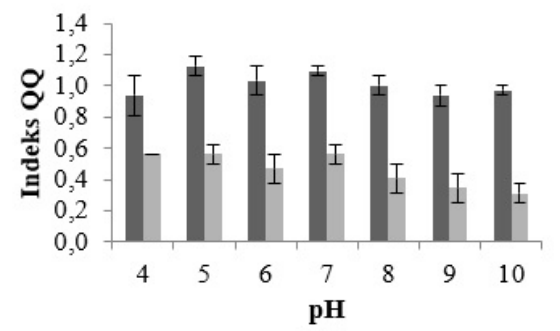

(A1)

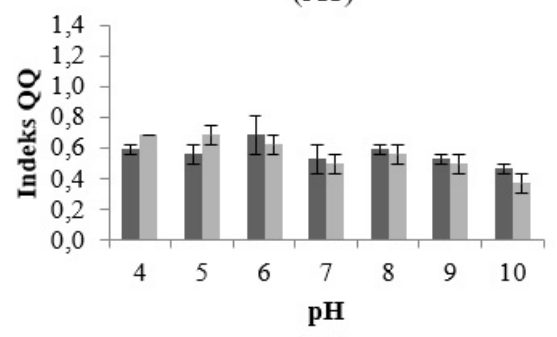

(B1)
Presipitat enzim ekstraseluler Bacillus cereus INT1c hasil pengendapan yang dipaparkan pada suhu $20-50{ }^{\circ} \mathrm{C}$ memiliki aktivitas yang relatif sama dan aktivitas tertinggi pada suhu $60{ }^{\circ} \mathrm{C}$ sedangkan enzim intraseluler memiliki aktivitas tertinggi pada suhu $40{ }^{\circ} \mathrm{C}$ (Gambar 4 A1). Enzim ekstraseluler dan intraseluler $B$. cereus INT1c hasil dialisis memiliki aktivitas tertinggi pada suhu $30^{\circ} \mathrm{C}$ dan aktivitasnya menurun drastis setelah pemanasan pada suhu 50 ${ }^{\circ} \mathrm{C}$ (Gambar 4 A2). Enzim ektraseluler Bacillus sp. NTT3a memiliki aktivitas tertinggi pada suhu $40{ }^{\circ} \mathrm{C}$ tetapi aktivitasnya tidak jauh berbeda pada suhu 30 ${ }^{\circ} \mathrm{C}$, sedangkan enzim intraseluler memiliki aktivitas tertinggi pada suhu $30-40^{\circ} \mathrm{C}$ (Gambar 4 B1). Enzim ekstraseluler dan intraseluler Bacillus sp. NTT3a hasil dialisis memiliki aktivitas tertinggi pada suhu $30-40{ }^{\circ} \mathrm{C}$ (Gambar 4 B2).

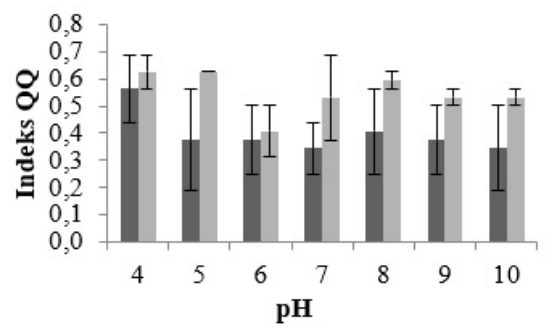

(A2)

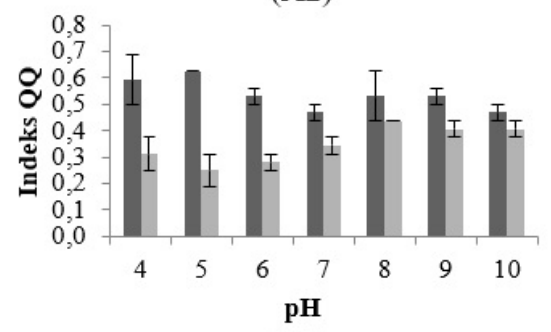

(B2)

Gambar 3. Indeks QQ (quorum quenching)AHL-laktonase B. cereus INT1c (A1) hasil pegendapan dan (A2) hasil dialisis; dan AHL-laktonase Bacillus sp. NTT3a (B1) hasil pemekatan dan (B2) hasil dialisis pada berbagai nilai pH ( $\square$ : enzim ekstraseluler; : enzim intraseluler) 


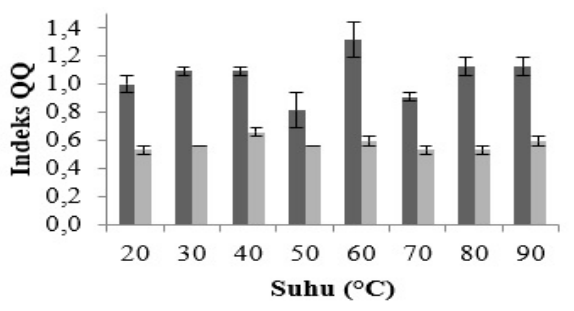

(A1)

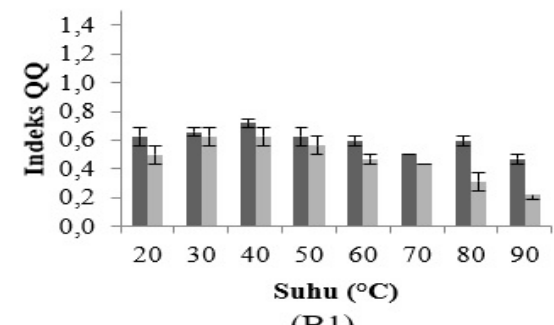

(B1)

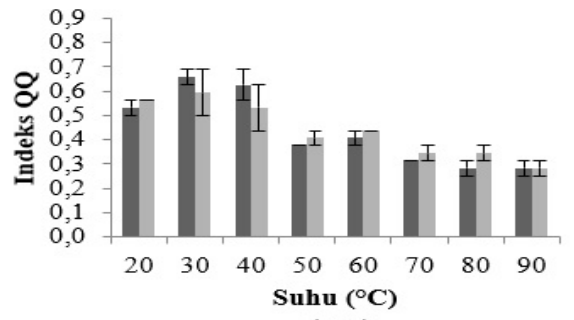

(A2)

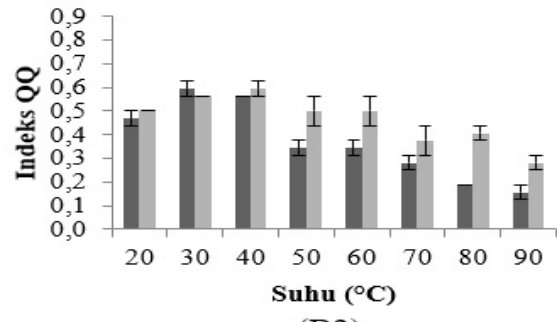

(B2)

Gambar 4. Indeks quorum quenching AHL-laktonase B. cereus INT1c (A1) hasil pegendapan dan (A2) hasil dialisis; dan AHLlaktonase Bacillus sp. NTT3a (B1) hasil pemekatan dan (B2) hasil dialisis pada berbagai suhu ( $\square$ : enzim ekstraseluler; : enzim intraseluler)

\section{PEMBAHASAN}

Kedua bakteri uji menghasilkan AHL-laktonase yang mampu menurunkan respon quorum sensing pada bakteri bioindikator Chromobacterium violaceum. Hal ini ditunjukkan oleh adanya zona quorum quenching di sekeliling paper disc yang mengandung ekstrak enzim. Bakteri bioindikator C. violaceum termasuk dalam kelompok bakteri Gram-negatif berbentuk batang yang menghasilkan AHL yang berperan sebagai media proses quorum sensing untuk mengaktifkan ekspresi antioksidan violacein (pigmen ungu) (McClean et al. 1997). Sintesis violacein melibatkan serangkaian enzim yang dikode oleh gen-gen dalam operon VioABCDE. Pada proses quorum sensing, sinyal AHL berperan sebagai inducer regulator gen CviR sehingga menjadi regulator positif bagi gen CviI (pengkode AHL) dan mengaktifkan ekspresi gen VioA (promoter pada operon Vio) (Hoshino 2011). AHL-laktonase memotong ikatan ester pada cincin lakton molekul AHL. AHL tidak dapat berikatan dengan CviR yang berperan sebagai regulator. Proses ini menyebabkan terhambatnya ekspresi promoter gen VioA dan regulasi positif untuk sintesis AHL dari gen CviI. Dengan demikian AHL-laktonase memiliki dua peran dalam menghambat quorum sensing pada C. violaceum yaitu menghambat sintesis enzim yang dibutuhkan untuk sintesis violacein dan menghambat produksi AHL yang berkelanjutan.

Kemampuan AHL-laktonase dalam menghambat quorum quenching telah banyak diujikan pada bakteri patogen yang mengaktifkan quorum sensing berbasis AHL seperti Erwinia carotovora penyebab penyakit busuk lunak. Penelitian Dong et al. 2000 menunjukkan bahwa ekpresi gen AHL-laktonase (yang berasal dari Bacillus thuringiensis) pada E. carotovora menyebabkan penurunan secara signifikan terhadap jumlah AHL melalui degradasi enzimatik pada molekul sinyal quorum sensing sehingga menyebabkan penurunan aktivitas enzim pektolitik dan menurunkan gejala penyakit busuk lunak E. carotovora pada kentang dan kubis.

Enzim AHL-laktonase aktif ditemukan pada enzim intraseluler dan ekstraseluler $B$. cereus INT1c dan Bacillus sp. NTT3a. Publikasi terdahulu menunjukkan bahwa AHL-laktonase dari beberapa Bacillus yang diuji berasal dari enzim intraseluler (Dong et al. 2002; Cao et al. 2012; Mukherji \& Prabhune 2015) tetapi hasil penelitian Fitriyah et al. 2015 menemukan bahwa aktivitas AHL-laktonase juga terdapat pada enzim ektraseluler (supernatan kultur) dari beberapa Bacillus yang diisolasi dari tanah pertanian.

AHL-laktonase dipisahkan dari media cair dengan proses pengendapan protein menggunakan amonium sulfat yang berperan untuk mengurangi kelarutan protein di dalam air sehingga terbentuk agregat protein yang dengan mudah dapat dipisahkan dari larutan dengan sentrifugasi (Scopes 1987). Proses pemekatan enzim dengan amonium diketahui efektif untuk memisahkan protein/enzim dari media cair, tetapi sisa garam amonium sulfat yang yang melekat pada molekul enzim dapat menutupi sisi aktif enzim sehingga menghambat proses katalisis. Sisa garam ammonium sulfat tersebut dapat dihilangkan dengan proses dialisis. Dialisis bertujuan untuk meningkatkan kemurnian enzim dengan menghilangkan sisa garam amonium sulfat dari proses pemekatan atau molekul pengotor berukuran kecil lain yang terdapat pada enzim.

Proses dialisis pada enzim ektraseluler $B$. 
cereus INT1c menyebabkan enzim menjadi lebih encer dan kadar proteinnya menurun (Tabel 1), tetapi meningkatkan aktivitas spesifik enzim AHL-laktonasenya dari 5.91 menjadi 29.96. Hal ini membuktikan bahwa penghilangan garam ammonium sulfat dapat meningkatkan aktivitas enzim. Hasil berbeda ditunjukkan oleh hasil dialisis enzim ektraseluler Bacillus sp. NTT3a. Enzim yang telah didialisis memiliki aktivitas spesifik (4.08) yang tidak jauh berbeda dengan hasil pengendapan (5.39). Penurunan aktivitas enzim setelah dialisis dapat disebabkan oleh beberapa faktor seperti enzim yang tidak stabil selama proses dialisis sehingga aktivitasnya menurun atau hilang, enzim terlarut dengan buffer dan menjadi lebih encer, enzim kehilangan kofaktor, atau terjadi proteolisis.

Enzim memiliki $\mathrm{pH}$ optimum yaitu $\mathrm{pH}$ di mana enzim dapat melakukan katalisasi paling optimum atau paling cepat. Nilai $\mathrm{pH}$ optimum ditentukan oleh asam amino yang menyusun sisi aktif enzim. Pada $\mathrm{pH}$ optimum, sebagian asam amino penyusun sisi aktif enzim menjadi bermuatan positif dan sebagian lagi negatif. Adanya interaksi elektrostatik yang timbul antar kedua jenis asam amino tersebut menyebabkan substrat dapat berikatan dengan sisi aktif dan terjadilah reaksi katalisis. Perubahan $\mathrm{pH}$ dari $\mathrm{pH}$ optimum menyebabkan perubahan muatan asam amino pada sisi aktif sehingga substrat tidak dapat berikatan lagi dengan sisi aktif. Perubahan $\mathrm{pH}$ juga menyebabkan perubahan struktur sekunder dan tersier dari enzim yang kemudian mempengaruhi kemampuannya untuk berikatan dengan substrat (Leskovac 2003).

Enzim intraseluler dan ekstraseluler $B$. cereus INT1c hasil dialisis memiliki aktivitas pada rentang $\mathrm{pH}$ yang luas tetapi paling optimal pada $\mathrm{pH}$ asam. Namun hasil dialisis enzim intraseluler Bacillus sp. NTT3a memiliki aktivitas optimal pada $\mathrm{pH}$ netral cenderung basa. Sebagai inhibitor quorum sensing, enzim yang memiliki aktivitas pada rentang $\mathrm{pH}$ yang luas dapat menguntungkan karena memungkinkan aplikasi pada kondisi yang lebih beragam. Hasil penetilitian sebelumnya menyebutkan bahwa aktivitas optimal AHL-laktonase berada pada pH netral cenderung basa (Chen et al. 2010; Cao et al. 2012; Sakr et al. 2013; Wang et al. 2004; Vinoj et al. 2014) karena penurunan $\mathrm{pH}$ dapat menyebabkan penutupan kembali cincin lakton yang telah dihidrolisis oleh AHL-laktonase (Yates et al. 2002; Chen et al. 2013). Aktivitas terbaik AHLlaktonase dari Bacillus sp. B546, Bacillus sp. A196 dan Bacillus weihenstephanensis P65 berada pada pH 6-9 (Chen et al. 2010; Cao et al. 2012; Sakr et al. 2013). Demikian pula aktivitas AHL-laktonase murni berada pada pH 6-9 (Wang et al. 2004).
Selain pH optimum, enzim juga memiliki suhu optimum, yaitu suhu di mana enzim berada pada struktur aslinya sehingga dapat bekerja paling optimum. Suhu tinggi dapat menyebabkan terlepasnya ikatan hidrogen pada rantai samping protein sehingga konfigurasi molekul protein/ enzim berubah dari kondisi normalnya.Perubahan tersebut bersifat dapat kembali (reversible) atau tidak dapat kembali (irreversible) yang juga dikenal dengan denaturasi (Mirsky dan Pauling 1936). Hasil penelitian Vinoj et al. (2014) aktivitas optimum AHL-laktonase dari Bacillus licheniformis DAHB1 terdapat pada suhu $30-50{ }^{\circ} \mathrm{C}$. Penelitian lain menunjukkan bahwa stabilitas AHL-laktonase terhadap suhu bervariasi bergantung pada strain penghasilnya. AHL-laktonase Bacillus sp. A196 memiliki aktivitas $67 \%$ setelah preinkubasi pada suhu $90{ }^{\circ} \mathrm{C}$ selama 3 menit (Cao et al. 2012) dan aktivitas enzim dari Bacillus sp. B546 sedikit menurun menjadi $80 \%$ setelah preinkubasi pada $70^{\circ} \mathrm{C}$ selama 30 menit (Chen et al. 2010). Jika dibandingkan dengan kedua bakteri dari penelitian tersebut, enzim AHL-laktonase INT1c dan NTT3a bersifat kurang tahan terhadap pemanasan dan memiliki aktivitas tertinggi pada kisaran suhu $30-40{ }^{\circ} \mathrm{C}$.

\section{SIMPULAN}

Bacillus cereus INT1c dan Bacillus sp. NTT3a menghasilkan enzim AHL-laktonase intraseluler dan ekstraseluler. Aktivitas spesifik enzim ektraseluler lebih tinggi daripada enzim intraseluler. Aktivitas spesifik enzim hasil dialisis tidak berbeda nyata jika dibandingkan aktivitas hasil pemekatan kecuali pada enzim ekstraseluler $B$. cereus INT1c. AHLlatonase hasil pengendapan dan dialisis kedua bakteri memiliki aktiitas pada rentang $\mathrm{pH}$ yang luas tetapi memiliki aktivitas yang lebih baik pada $\mathrm{pH}$ asam. AHL-laktonase hasil dialisis dari kedua bakteri tidak tahan terhadap pemanasan suhu tinggi dan memiliki aktivitas optimum pada suhu $30-40^{\circ} \mathrm{C}$.

\section{UCAPAN TERIMA KASIH}

Ucapan terima kasih penulis sampaikan kepada DIKTI melalui Beasiswa BPPDN (Beasiswa Pascasarjana Dalam Negeri) tahun 2013/2014 dan Laboratorium Mikrobiologi IPB yang telah mendukung penelitian ini.

\section{DAFTAR PUSTAKA}

Afiah TSN. 2011. Isolasi dan karakterisasi bakteri penghasil Acyl Homoserine Lactonase(AHL-laktonase) asal lahan pertanian di Jawa [skripsi]. Bogor (ID): Institut Pertanian Bogor 
Bradford MM. 1976. A Rapid and sensitive method for the quantitation of microgram quantities of protein utilizing the principle of proteindye binding. Anal Biochem. 72:248-254.

Cao Y, He S, Zhou Z, Zhang M, Mao W, ZhangH, YaoB. 2012. Orally administered thermostable N-Acyl homoserine lactonase from Bacillus sp. strain AI96 attenuates Aeromonas hydrophila infection in zebrafish. ApplEnviron Microbiol. 78(6):1899-1908

Chen R, Zhou Z, Cao Y, Bai Y, Yao B. 2010. High yield expression of an AHL-lactonase from Bacillus sp. B546 in Pichia pastoris and its application to reduce Aeromonas hydrophila mortality in aquaculture. Microb Cell Factories. 9:39

Chen F, Gao Y, Chen X, Yu Z, Li X.2013. Quorum quenching enzymes and their application in degrading signal molecules to block quorum sensingdependent infection. Int J Mol Sci.14: 17477-17500

de Kievit TR, Iglewski BH. 2000. Bacterial quorum sensing in pathogenic relationship. JInfect Immun. 68(9): 4849-4849

Dell'Acqua G, Giacometti A, Cironi O, Ghiselli R, Saba V, Scalise G, et al. 2004. Suppressionof drug-resistant staphylococcal infections by the quorum-sensing inhibitorRNAIIIinhibiting peptide. $J$ Infect Dis. 190:316-20.

Dong YH, Xu JL, Li XC, Zhang LH. 2000. AiiA, a novel enzyme inactivates acyl-homoserine-lactone quorumsensing signal and attenuates the virulence of Erwinia carotovora. Proc Natl Acad Sci. 97(7): 3526-3531.

Dong YH, GustiAR, Zhang Q, XuJL,Zhang LH. 2002. Identification of quorum-quenching $\mathrm{N}$-acyl homoserine lactones from Bacillus species. Appl Environ Microbiol. 68: 1754-1759.

Dong YH, Zhang LH. 2005. Quorum sensing and quorumquenching enzymes. $J$ Microbiol. 43: 101-109

Fitriyah A. 2011. Isolasi dan karakterisasi bakteri penghasil AHL-laktonase asal lahan pertanian luar Pulau Jawa [skripsi]. Bogor (ID): Institut Pertanian Bogor

Fitriyah D, Wahyudi AT, Rusmana I. 2015. Characterization of bacteria producing Acyl Homoserine Lactone (AHL) lactonase from agricultural lands. $\quad A d v$ Environ Biol.9(8): 140-148.

Hoshino T. 2011. Violacein and related tryptophan metabolites produced by Chromobacterium violaceum: biosynthesis mechanism and pathway for construction of violacein core. Appl Microbiol Biotechnol. 91: 1463-1475

Huang JJ, Han JI, Zhang LH, Leadbetter JR. 2003. Utilization of acyl-homoserine lactone quorumsignals for growth by a soil pseudomonad and Pseudomonas aeruginosaPAO1. Appl Environ Microbiol. 69: 5941-9.
Kalia VC, 2013. Quorum sensing inhibitors: An overview. Biotechnol Adv. 31: 224-245

Leskovac V. 2003. Comprehensive Enzyme Kinetics. New York (US): Kluwer Academic Publishers

McClean KH, Winson MK, Fish L, Taylor A, Chhabra SR , Camara M, Daykin M, Lamb JH, Swift S, Bycroft BW, Stewart GSAB, Williams P. 1997. Quorum sensing and Chromobacterium violaceum: exploitation of violacein production and inhibition for the detection of N-acylhomoserine lactones. Microbiol. 143: 3703-3711

Mirsky AE, Pauling L. 1936. On the structure of native, denatured, and coagulated proteins. Proc Natl Acad Sci $U$ S A.22(7): 439-447

Mukherji R, Prabhune A. 2015. Enzyme purification and kinetic characterization of AHL lactonase from Bacillus sp.RM1 a novel and potent quorum quencher isolated from Fenugreek root nodule rhizosphere. Int J Curr Microbiol App Sci. 4(1): 909-924

Rasko DA, Sperandio V. 2010. Anti-virulence strategies to combat bacteria-mediated disease. Nat Rev Drug Discov. 9(2): $117-128$

Sakr MM, Aboshanab KMA, Aboulwafa MM, Hassouna NA. 2013. Characterization and complete sequence of lactonase enzyme from $\mathrm{B}$ acillus weihenstephanensis isolate $\mathrm{P} 65$ with potential activity against acyl homoserine lactone signal molecules. BioMed Res Int 1-12

Scopes RK. 1987. Separation by Precipitation. Protein Purification: Principle and practice. Edisi ke-3. New York (USA): Springer-Verlag. 41-71

Vinoj G, Vaseeharan B, Thomas S, Spiers AJ, Shanthi S. 2014. Quorum-quenching activity of the ahl-lactonase from Bacillus licheniformis DAHB1 inhibits Vibrio biofilm formation in vitro and reduces shrimp intestinal colonisation and mortality. Mar Biotechnol. doi 10.1007/ s10126-014-9585-9

Wang LH, Weng LX, Dong YH, Zhang LH. 2004. Specificity and enzyme kinetics of the quorum-quenchingN-Acyl homoserine lactone lactonase (AHL-lactonase). J Biol Chem. 279(14): 13645-13651

Yates EA, Philipp B, Buckley C,Atkinson S, Chhabra SR, Sockett RE, Goldner M, Dessaux Y, Ca'mara M, Smith H, Williams P. $2002 \mathrm{~N}$-acylhomoserine lactones undergo lactonolysis in a $\mathrm{pH}-$, temperature-, and acyl chain length-dependent manner during growth of Yersinia pseudotuberculosis and Pseudomonas aeruginosa. Infect Immun. 70(10): 5635-46. 